\title{
Zömítö tompahegesztéssel toldott betonacél szálak alkalmazhatóságának vizsgálata
}

\section{Analysis of Applicability of Upset Welded Ribbed Steel Bars for Concrete Reinforcement}

Rendeltetés, szerkezet, anyaghasználat és mobilitás szerint különféle létesitmények állnak a hadiipar szolgálatában. Jelen cikk a betonacél-erösítésü konstrukciókkal foglalkozik, amelyek például hidak, csarnokok, védö és kiszolgáló épületek szerkezetében fordulnak elő. Mivel a betonacél szálak hosszúsága gyártásilag - különösképp a nagyobb átméröjüek esetében - korlátozott, illetve a gazdaságos felhasználás érdekében sok esetben szükséges az egyes szálak toldása, aminek lehetőségeit európai sza bványok szabályozzák. Jelen kutatás célja a hazai viszonylatban még nem alkalmazott betonacél toldási módjának alkalmazási kockázatértékelése és az esetleges teherbírás-csökkenés okainak feltárása laboratóriumi vizsgálatokkal. Zömítő tompahegesztéssel toldott betonacél szálak keresztirányú szakítóvizsgálatát, illetve átfogó anyagvizsgálatát végeztük el a kötéstípus pontos tulajdonságainak meghatározása érdekében. Megállapítottuk, hogy a hegesztett szálak egytengelyü húzó igénybevétellel szembeni ellenállása átlagosan körülbelül 80\%-a az alapanyagénak, illetve a hajlitott tartó teherbírását is nagyjából ilyen mértékben befolyásolja a toldott szálak alkalmazása. A hagyományos metallográfiai vizsgálatok eredményei megfelelnek a vonatkozó szabványok elöírásainak, így a vizsgált technológia a kockázati tényezök körültekintő figyelembevételével alkalmazható az emlitett szerkezetekben.

Kulcsszavak: betonacél, zömítő tompahegesztés, minőségbiztosítás, anyagvizsgálat

Széchenyi István Egyetem Audi Hungaria Járműmérnöki Kar Anyagtudományi és Technológiai Tanszék, tanársegéd, e-mail: harangozo.dora@sze.hu

2 Széchenyi István Egyetem Építész-, Építő- és Közlekedésmérnöki Kar Szerkezetépítési és Geotechnikai Tanszék, tanársegéd, e-mail: harrach.daniel@sze.hu 
Different establishments distinguished by function, structure, material usage or mobility are used in military industry. Constructions reinforced by steel bars are examined in this paper which are installed in the structure of bridges, halls or buildings. Because the length of the reinforcement steel is limited by the production technology - especially at the bigger diameters - and for economic reasons, extension of the bars is necessary in many cases which is regulated by European standards. Transversal tensile tests of reinforcement steel bars joint by upset welding were carried out in order to determine the accurate attributions of this joint type. The resistance against uniaxial tension of the welded bars were approximately $80 \%$ of the raw material and the load capacity of a bended structure is affected in a similar manner. Results of traditional metallurgical tests meet the requirements of the relevant standards, so this technology is applicable with prudent consideration of the risk factors.

Keywords: reinforcement steel, upset welding, quality assurance, material testing

\section{Bevezetés}

A manapság rendkívül elterjedt, különböző igénybevételeknek kitett vasbeton olyan kompozit alapanyagú tartószerkezet, amelyben megvalósul a beton és a betonacélok közös teherviselése. A beton a nyomó-, a betonacél a húzófeszültségeket veszi fel. Az első betonacélokra vonatkozó szabályozás 1910-ben jelent meg, azóta a múlt század során különböző szabványokat dolgoztak ki, amelyek az elvárt szállítási és felhasználási feltételeket tartalmazzák. Természetesen az acélgyártás fejlődésével újabb gyártástechnológiák, illetve eljárások is megjelentek: például az 1950-es években az amerikai haditengerészet elkezdett galvanizált betonacél szálakat használni a Bermuda-területen történő hídépítés során. ${ }^{3}$ Sok publikáció jelent meg, amelyek a különböző típusú betonacél szálak mechanikai tulajdonságait, bizonyos igénybevételekkel szembeni ellenállását, mikroszerkezetét tárgyalják. ${ }^{4} \mathrm{Az}$ acélbetétek gyártási hossza szükségessé teszi a vasbeton szerkezetek vasalásának toldását. Általánosságban azt lehet mondani, hogy a szokványos gyártási szálhosszúság $6,0 \mathrm{~m}$ a betonacél átmérőjétől függetlenül. Különleges igények esetén, az arra alkalmas gyártóüzemek 9,0-12,0 m hosszúságban is képesek betonacélokat gyártani. ${ }^{5}$ Magasépítési és hídépítési vasbeton szerkezetek esetén ebből a gyártási hosszból azonban nem lehet kialakítani a megfelelő betonacél armatúrát. A 6 m szerkezeti hosszat meghaladó, vagy egyedi (nem csak húzott betonacélokat tartalmazó) vasbeton

3 Susan Lane-Danielle Kleinhans: FHWA LTBP Summary. National Changes in Bridge Practices for Reinforcing Bars. Concrete Reinforcing Steel Institute and Chair - National Concrete Bridge Council, 2016.

4 Dan Song et al.: Microstructure and deformation behavior of anovel steel rebar. Effect of the heterogeneous microstructure of soft ferrite and hard bainite. Journal of Materials Research and Technology, (2020), 12281-12292; Yukun Lv et al.: Microstructure evolution of 400 MPa class rebar produced by QST and VNM technology under the high strain and low cycle fatigue. Construction and Building Materials, 229. (2019), 116889; Dongming Yan et al.: Microstructural and mechanical characterization of the interface between concrete and chemically reactive enamel (CRE) coated rebar. Construction and Building Materials, (2020). 263; Jie Wei - Junhua Dong - Wei Ke: Corrosion resistant performance of a chemical quenched rebar in concrete. Construction and Building Materials, 25. (2011), $1243-1247$.

5 Taylan Altan - Ngaile Gracious - Shen Gangshu: Cold and Hot Forging Fundamentals and Application. Ohio State University, 2004 
szerkezetek esetén szükséges lehet a betonacélok toldása. Az érvényes tervezési szabályozás az Eurocode-2 elöírása ${ }^{6}$ értelmében magasépítési vasbeton szerkezetek esetén egy keresztmetszetben az acélbetétek 1/4-ét - 1/3-át lehet toldani. A toldási előírások a hagyományos átlapolásos toldásra vonatkoznak. Egy másik lehetőség a kohéziós kapcsolat létesítése az acélszálak között, ami hegesztéstechnológiákkal valósítható meg. Hővel, nyomással vagy mindkettővel létrehozott nagy szilárdságú, oldhatatlan, gyakorlatilag homogén kötéseket nevezünk hegesztésnek, amelynek során a munkadarabok között fémes (kohéziós) kapcsolat jön létre. ${ }^{7}$ A hegeszthetőség az acélokra általánosan jellemző módon a széntartalom függvénye, elsődlegesen ez, illetve az átmérő határozza meg, hogy hegeszthető-e a betonacél, és ha igen, igényel-e előmelegítést. ${ }^{8} \mathrm{~A}$ hagyományos átlapolásos toldásos eljáráshoz képest a zömítő tompahegesztésekkel egy-egy tartószerkezeti elemre vonatkozóan akár 3-5\%-os betonacél alapanyag-mennyiség is megspórolható. Olyan területen (ilyen például a hadiipar is), ahol a nagy teherbírás mellett kiemelten fontos a gazdaságossági kérdés, elengedhetetlen az ilyen technológiák használata. Kutatási munkánk során a zömítő tompahegesztéssel toldott betonacélok anyagvizsgálatait fogjuk elvégezni, és értékeljük a vizsgálati eredményeket. Egy új - egyedi - technológia bevezetése előtt szükség van annak megismerésére, hogy alkalmazása rendelkezik-e valamilyen negatív tulajdonsággal. Értékelni kell a próbatestek viselkedését, valamint teoretikusan a szerkezeti kölcsönhatásokat is, ennek befejezése után van lehetőség áttérni a tényleges tartószerkezeti alkalmazásra. A cikkünk ennek a folyamatnak fontos részét képezi.

\section{Megoldások a betonacél szálak meghosszabbítására}

A modern építőipar igényeinek megfelelően a szerkezetek tervezésénél elődleges követelmény a gazdaságosság, ezért a tartószerkezeteket a biztonság és legkisebb keresztmetszet szempontjából optimalizálják. Vasbeton esetében ez azt jelenti, hogy kis szerkezeti szélességü/magasságú szerkezeteket kell tervezni. A méretezés során egy másik fontos szempont a betonacél rudak közötti megfelelő távolság biztosítása, ${ }^{9}$ amit az (1) képlet szerint határozunk meg:

$$
\mathrm{a}_{\min }=\max \left(\varnothing ; 20 \mathrm{~mm} ; \mathrm{d}_{g}+5 \mathrm{~mm}\right)
$$

$\mathrm{a}_{\min }$ - a betonacél rudak között minimálisan szabadon tartandó távolság [mm] $\varnothing$ - betonacél átmérője [mm]

6 MSZ EN 1992-1-1:2004/A1:2016 Eurocode 2: „Betonszerkezetek tervezése. 1-1. rész: Általános és az épületekre vonatkozó szabályok".

7 Gunczer László: Anyagismeret és gyártástechnológia - Hegesztések modul. Szeged, Universitas-Szeged, 2009.

8 Gillemot László: Szerkezeti anyagok technológiája ll. - Hegesztések. Budapest, Tankönyvkiadó, 1965; Baránszky-Jób Imre: Hegesztési kézikönyv. Budapest, Müszaki Könyvkiadó, 1985; Ferenc Tancsics - Tamás Ibriksz: Determining the optimum heating time of small sized test specimen made from weldable mild steel. IOP Conference Series. Materials Science and Engineering, 2020. 903.

9 Farkas György et al.: Betonszerkezetek méretezése az Eurocode alapján. Közúti hidak, épületek. Budapest, TERC, 2008. 
$\mathrm{d}_{\mathrm{g}}$ - a beton adalékanyagának maximális szemcseátmérője [mm]

Ennek tekintetében belátható, hogy a túl sürü háló elkerülése érdekében a tervező mérnöknek a betonacél szálak toldási lehetőségeit is figyelembe kell venni a megfelelő armatúra kialakításához.

\section{1. Átlapolásos toldás}

Az átlapolásos toldás esetén (1. ábra) nincs mechanikai kapcsolat a két toldott betonacél szál között, ezért biztosítani kell a megfelelő lehorgonyzási hossz betartását. Emiatt a toldási hossz értéke - betonacél-átmérőtől függően - akár $200 \mathrm{~mm}$ is lehet. ${ }^{10} \mathrm{Az}$ általában alkalmazott, a tervezett toldási hosszaknak megfelelő mértékü átfedéssel kialakított toldások esetén az acélbetéteket nem szabad összekötözni, mert az acélbetéteket a beton nem képes körülvenni, így nem látja el feladatát. A hagyományos átlapolásos toldás ${ }^{11}$ esetén ez komoly betonacél-torlódást tud okozni, ahol nem öleli körbe megfelelő mennyiségű betonágy a betonacél rudakat.

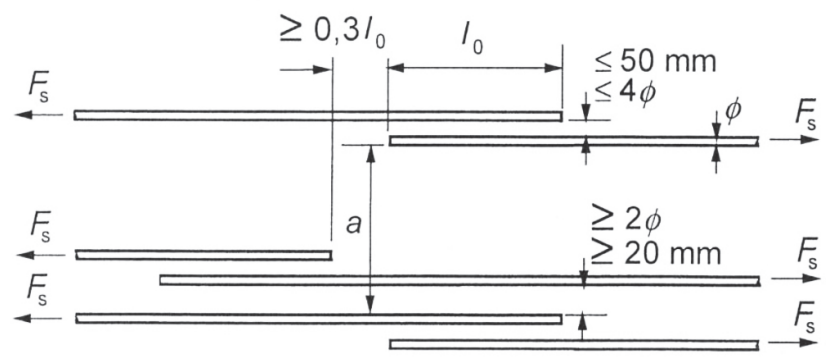

1. ábra. Átlapolásos toldások kialakítása

Forrás: Deák et al. (2016): i. m. 14.

A gazdaságossági szempont és a statikailag meghatározott vashányad biztosítása azt okozza, hogy a betonban sürün helyezkednek el a betonacél rudak.

\subsection{Kötőelemes toldások}

A 12-40 mm-es átmérővel hazánkban is gyártott menetbordás acélok toldását belső menetű csőhüvelyek felhasználásával is meg lehet oldani, ahol a menetbordára illeszkedő szárnyas csavarokkal feszítik össze a zsaluhéjakat. Az eljárással a menetbordás betonacélokon kívül öszszekapcsolhatók sima betonacélok és pászmák is, valamint egy menetes végü és egy rovátkolt acél, vagy betonacélok átfedéssel is. Sőt egyik oldalról két, a másik oldalról egy kapcsolódó betonacél, akár oldhatatlan akár - bordázott acélok esetében - oldható kötésekkel. A toldási módszer előnye, hogy üzemben és az építés helyszínén egyaránt alkalmazható, időjárásra

Farkas et al. (2008): i. m. 7.

11 Deák György et al.: Vasbeton szerkezetek. Tervezés az Eurocode alapján. Budapest, Arfitex, 2016. 
érzéketlen, élőmunka igénye a hegesztésnek csak 1/5-e, használata néhány óra alatt betanítható (2. ábra).

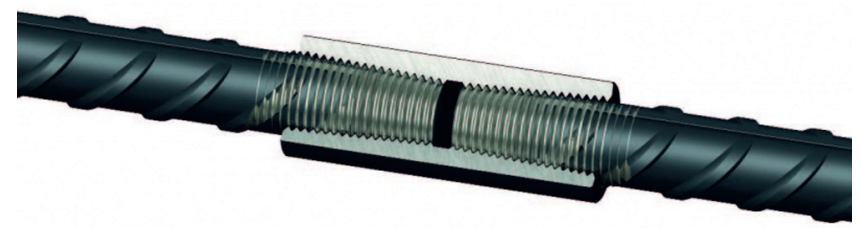

2. ábra. TTS belső menetes betonacél toldóelem

Forrás: Ancon Building Products: Menetes és menetmentes betonacéltoldó szerkezetek. Bauhaus, 2012.

\subsection{Hegesztéses toldás}

A 19. század vége óta használják a villamos ív energiáját hegesztési célokra, és még a századforduló előtt szabadalmaztatták a leolvadó elektródákat, illetve az ellenállás-hegesztés technológiáját is. Természetesen a világháborúk általános technológiai serkentő hatása a hegesztés fejlődését és széles körű elterjedését is eredményezte. Bővült a hegeszthető anyagfajták sora, különös tekintettel a könnyű-, színes- és különleges fémötvözetekre, ami az 1930-as években a semleges védőgázas, wolframelektródás ívhegesztés kifejlesztését is előidézte. A tömegygyártás igénye a technológiák gépesítésének szükségességét is jelentette. Az autóiparban és a repülőgépiparban az ellenállás- és a dörzshegesztés jutottak nagy szerephez. Betonacélok esetében a B.38.24, B.45.30 és B.50.36. anyagminőségek ívhegesztéssel is, míg a B.60.40-es minőség csak tompa ellenállás-hegesztéssel toldható. Ennél a típusú jelölésnél a „B" betű utáni első két számjegy az acél legkisebb húzószilárdságát, az utána következő két számjegy pedig a folyáshatárt jelöli, $\mathrm{N} / \mathrm{mm}^{2}$-ben kifejezve, illetve a jelölésből a szelvényalakra is lehet következtetni. Emellett használatos még a Bxxx jelölés is, ahol a „B” betű utáni három számjegy az anyagtól elvárt folyáshatár $\mathrm{N} / \mathrm{mm}^{2}$-ben. ${ }^{12}$

MSZ EN ISO 17660-1:2007 szabvány ${ }^{13}$ a következő hegesztési eljárásokat határozza meg betonacélok esetén:

- tompahegesztés: bevont elektródás ívhegesztés, leolvasztó tompahegesztés, zömítő tompahegesztés, dörzshegesztés, sajtoló gázhegesztés;

- átlapolt kötés: önvédő porbeles huzalos ívhegesztés, ellenállás-ponthegesztés;

- keresztkötés: fogyóelektródás, aktív védőgázos ívhegesztés (MAG-hegesztés), dudorhegesztés;

- egyéb kötések: fogyóelektródás, aktív védőgázos ívhegesztés porbeles huzalelektródával, dörzshegesztés.

12 Közlekedés- és Postaügyi Minisztérium: Különleges feltételek a közúti hidak betonacél hegesztésére. Budapest, 1967.

13 MSZ EN ISO 17660-1:2007 „Hegesztés. Betonacélok hegesztése. 1. rész: Teherhordó hegesztett kötések”. 
A zömítő tompahegesztés hozaganyag nélkül, nyomás alatt végzett sajtolóhegesztés. Ezt a hegesztési módot általában rúd- vagy csőszerü anyagok esetében alkalmazzák, amelyeknél az érintkezésbe kerülő homlokfelületük mentén, áramátvezetés révén felhevítik, majd tengelyirányú erőhatással zömítik. ${ }^{14}$ A 3 .a ábra szerinti elrendezésben a munkadarabok a befogópofákon keresztül a hegesztőtranszformátor szekunder kapcsaihoz csatlakoznak, amelyek közül az egyik rögzített, a másik elmozdítható. A fejlődő hő és az erőhatás együttesen nagyfokú képlékenyalakítást hoz létre, ami megteremti a kohéziós kapcsolatot a két anyag között. Fontos a megfelelően nagy alakítási mérték, illetve az érintkező felületek szolidusz feletti hőmérsékletének biztosítása, hogy a felületeken lévő vagy a hevítés során keletkező szennyeződések, oxidok a sorjába nyomódjanak. Nagy keresztmetszeteknél ez nem is mindig biztosítható. ${ }^{15} \mathrm{~A}$ 3.b ábrán látható az eljárás munkarendje, ahol:

- F: a munkadarabra ható nyomóerö;

- I: az áramerősség;

- l: a mozgó befogópofa elmozdulása;

- t: az idő.

A lágyacélok hegesztéséhez szükséges áramsürüség $70-80 \mathrm{~A} / \mathrm{mm}^{2}$, az összeszorító nyomás 0,5-2,0 bar, a zömítéshez szükséges nyomás 1,5-3,0 bar, a helytelenül megválasztott áramerősség káros metallurgiai folyamatokhoz (szemcsedurvulás) vezet, ami rontja a túlhevült övezet szívósságát. Az eljárás során végbemenő zömítés miatt a munkadarabokat ráhagyással kell terveznünk, amelynek mértéke $\varnothing 4-10 \mathrm{~mm}$ esetén $0,75-1,5 \mathrm{~mm} .^{16}$
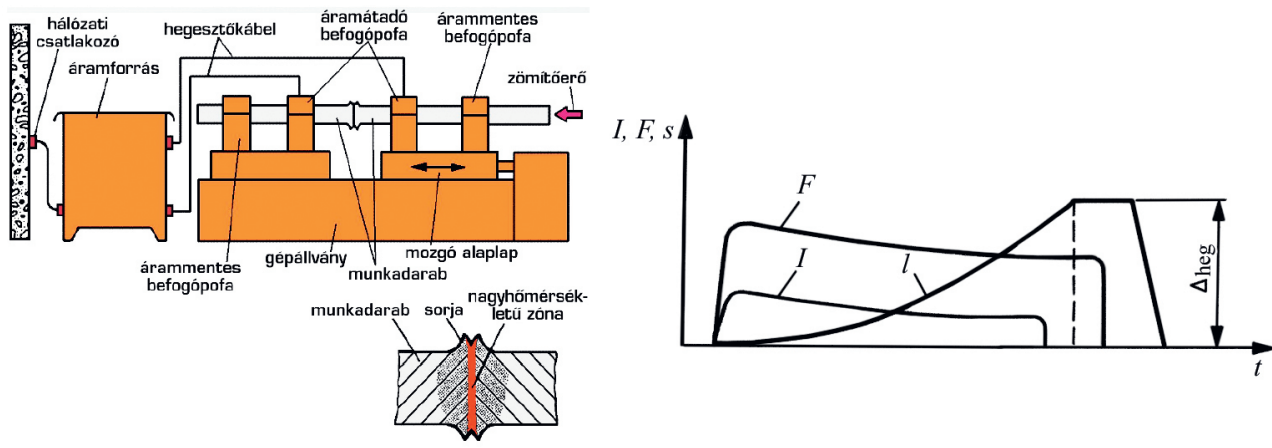

3. ábra. A zömítő ellenálláshegesztés a) elvi ábrája, b) munkarendje

Forrás: Gáti (1995): i. m. 19-20.

4 Bagyinszki Gyula - Czinege Imre: Fémek gyártási eljárásai. Győr, Széchenyi István Egyetem, 2006.

15 Gáti József: Hegesztési zsebkönyv. Budapest, Műszaki Könyvkiadó, 1995.

16 Gáti (1995): i. m. 8. 


\section{Hegesztett kötések minősége és vizsgálata}

A hegesztett betonacél kötéseknek vizuális, radiográfiai, hajlító-, szakító-, fárasztó-, ütőés csiszolatvizsgálatokra előírt követelményeknek kell megfelelniük. Ezekkel a vizsgálatokkal az alábbi, megengedhetetlen hibák jelenlétét kell kimutatni:

- illesztési hiba;

- felületre tört gázzárványok;

- keresztmetszethiány;

- szegélykiolvadás;

- repedések, salak- és gázzárványok.

Az acél- és alumíniumszerkezetek kivitelezését érintő műszaki minőségügyi kérdéseket az MSZ EN 1090-2:2018 szabvány ${ }^{17}$ tartalmazza. A szabvány négy kiviteli osztályt különböztet meg (EXC1-EXC4), amelyekkel szemben támasztott követelmények az EXC4 osztály felé haladva emelkednek. Minden osztályhoz meghatározza a feltételeket, a dokumentációt, az előkészítést, a hegesztést, a türéseket és az elvégzendő vizsgálatokat illetően.

\subsection{Kiviteli osztály meghatározása}

Az építőipar szempontjából különösen fontos annak mérlegelése, hogy egy új technológia alkalmazásának milyen kockázata van (a már használatos eljárásokhoz képest). Egy új eljárás, építőanyag alkalmazása nem feltétlenül jelent biztonsági/teherbírási kockázatot, viszont ennek értékelése elengedhetetlen része a folyamatnak, még a beépítés megkezdése előtt, a tervezés szakaszában. A kiviteli osztály (a kockázati értékelés alapja) meghatározása négy lépésben történik, a következőkben részletezett módon.

\subsubsection{A kárkövetkezmény-osztályok (káreseti veszélyesség) meghatározása}

Az MSZ EN 1090-2:2018 szabvány ${ }^{18}$ a következő szempontok figyelembevételét írja elő a szerkezet(ek) káreseti veszélyességi kategóriájának meghatározásánál. Például egy irodaházban beépítésre kerülő betonacél a CC2-es veszélyességi kategóriába kerül. A CC1-től a CC3 kategória felé haladva egyre nagyobb mértékü az emberéletre gyakorolt hatás. Az 1. táblázat a szabvány szerinti kategorizálást tartalmazza.

\footnotetext{
17 MSZ EN 1090-2:2018 „Acél- és alumíniumszerkezetek kivitelezése. 2. rész: Acélszerkezetek műszaki követelményei".

18 MSZ EN 1090-2:2018. i. m. 18.
} 
1. táblázat. A kárkövetkezmény-osztályok (káreseti veszélyesség) meghatározása

\begin{tabular}{|l|l|l|}
\hline $\begin{array}{c}\text { Kárkövetkez- } \\
\text { mény-osztály }\end{array}$ & \multicolumn{1}{|c|}{ Jellemzök } & \multicolumn{1}{|c|}{ Példák } \\
\hline CC1 & $\begin{array}{l}\text { Kis kár az emberéletben és kis vagy elhanyagolható gaz- } \\
\text { dasági, szociális vagy környezeti következmények. }\end{array}$ & $\begin{array}{l}\text { Rendszeres emberi jelenlét nélküli mezögazda- } \\
\text { sági épületek (például tároló színek, növény- } \\
\text { házak). }\end{array}$ \\
\hline CC2 & $\begin{array}{l}\text { Közepes mértékü kár az emberéletben és jelentős } \\
\text { gazdasági, szociális vagy környezeti következmények. }\end{array}$ & $\begin{array}{l}\text { Lakó- és irodaházak, közepes káreseményt } \\
\text { jelentö középületek. }\end{array}$ \\
\hline CC3 & $\begin{array}{l}\text { Nagymértékủ kár az emberéletben és rendkivül jelentős } \\
\text { gazdasági, szociális vagy környezeti következmények. }\end{array}$ & $\begin{array}{l}\text { Lelátók, nagy kárkövetkezményt jelentő } \\
\text { középületek (például koncerttermek). }\end{array}$ \\
\hline
\end{tabular}

Forrás: MSZ EN 1090-2:2018. i. m. 18.

\subsubsection{Az igénybevételi kategóriák meghatározása}

A szerkezet igénybevételét tekintve két kategória került elkülönítésre, amelyeket a 2. táblázat mutat be. A jellemzően statikus igénybevételekre méretezett elemek az SC1, míg a jelentős dinamikai hatásoknak kitett szerkezetek az SC2 kategóriába tartoznak.

2. táblázat. Az igénybevételi kategóriák meghatározása

\begin{tabular}{|l|l|}
\hline \multicolumn{1}{|c|}{ Igénybevételi kategóriák } & \multicolumn{1}{c|}{ Jellemzök } \\
\hline SC1 & $\begin{array}{l}\text { • Jellemzően nyugvó igénybevételre méretezett tartószerkezetek, alkatrészek (például } \\
\text { épületek). }\end{array}$ \\
& $\begin{array}{l}\text { Kis földrengés-veszélyességü országokban földrengésre méretezett kötésekkel rendelkező } \\
\text { tartószerkezetek, alkatrészek. }\end{array}$ \\
\hline SC2 & $\begin{array}{l}\text { Az EN } 1993 \text { szerint kifáradásra méretezett tartószerkezetek és alkatrészek (például közúti } \\
\text { és vasúti hidak, daruk, szélterhelésnek kitett tartószerkezetek). } \\
\text { Közepes vagy nagy földrengés-veszélyességü országokban földrengésre méretezett } \\
\text { kötésekkel rendelkező tartószerkezetek, alkatrészek. }\end{array}$ \\
\hline
\end{tabular}

Forrás: MSZ EN 1090-2:2018. i. m. 18.

\subsubsection{A gyártással kapcsolatos veszélyek meghatározása}

A szerkezeti elemek kialakítása, gyártási módja szerint további alkategóriák használatára van lehetőség (3. táblázat). Ennél az osztályozásba sorolásnál az acélanyag gyártása során kialakuló alakítási szilárdságot vesszük figyelembe. 
3. táblázat. A gyártással kapcsolatos veszélyek meghatározása

\begin{tabular}{|c|c|}
\hline Gyártási kategóriák & Jellemzök \\
\hline PC1 & $\begin{array}{l}\text { - Nem hegesztett alkatrészek, bármilyen acélminőségből. } \\
\text { - Hegesztett alkatrészek, S355 alatti acélminőségből. }\end{array}$ \\
\hline PC2 & $\begin{array}{l}\text { - Hegesztett alkatrészek, S355 és afölötti acélminőségek. } \\
\text { - Az állékonyság szempontjából lényeges alkatrészek, amelyeket a helyszínen hegesztenek össze } \\
\text { egymással. } \\
\text { - Melegen alakított vagy a gyártás során hőkezelt alkatrészek. } \\
\text { - Csövekből összeállitott rácsos tartók, amelyek végkeresztmetszetein különleges vágások } \\
\text { szükségesek. }\end{array}$ \\
\hline
\end{tabular}

Forrás: MSZ EN 1090-2:2018. i. m. 18.

\subsubsection{A kiviteli osztály meghatározása}

Az előzőekben meghatározott következmény, igénybevételi és gyártási kategóriák alapján kerül meghatározásra a 4. táblázat szerint a kiviteli osztály. Az EXC1-től az EXC4 kategóriák felé haladva növekszik a kockázat. Az egyes csoportokra különböző szabályok vonatkoznak a kivitelezés/gyártás és a minőség-ellenőrzés során is.

4. táblázat. A kiviteli osztály meghatározása

\begin{tabular}{|l|c|c|c|c|c|c|c|}
\hline \multicolumn{2}{|c|}{ Következményosztályok } & \multicolumn{2}{c|}{ CC1 } & \multicolumn{2}{c|}{ CC2 } & CC3 \\
\hline \multicolumn{2}{|l|}{ Igénybevételi kategóriák } & SC1 & SC2 & SC1 & SC2 & SC1 & SC2 \\
\hline Gyártási kategóriák & PC1 & EXC1 & EXC2 & EXC2 & EXC3 & EXC3a & EXC3a \\
\cline { 2 - 9 } & PC2 & EXC2 & EXC2 & EXC2 & EXC3 & EXC3a & EXC4 \\
\hline $\begin{array}{c}\text { a) EXC4-et különleges vagy nagy kárkövetkezményekkel járó szerkezetek esetén kell alkalmazni, } \\
\text { összhangban a nemzeti elöírásokkal. }\end{array}$ & & & \\
\hline
\end{tabular}

Forrás: MSZ EN 1090-2:2018. i. m. 18.

\section{Felhasznált anyagok és módszerek}

Annak érdekében, hogy összehasonlíthatók legyenek a különböző betonacéltoldási technológiák, laboratóriumi körülmények között megvizsgáltuk a zömítö tompahegesztéssel készített próbatestek (4. ábra) föbb anyagtulajdonságait, illetve a kapcsolat teherbírását is. A hagyományos átlapolt toldás esetén nincs lehetőség a toldás teherbírásának vizsgálatára, hiszen ebben az esetben (a 2.1. fejezetben részletezettek szerint) nincs kapcsolat a két elem között. 


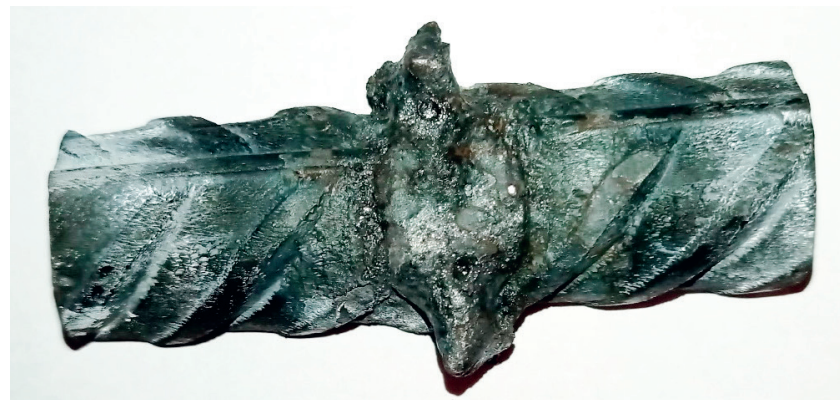

4. ábra. A vizsgálati próbatest

Forrás: a szerzők felvétele

A vizsgált minta kémiai összetételét MSZ EN 10080:2005 „Betonacél. Hegeszthető betonacél. Általános követelmények" szabvány ${ }^{19}$ az 5 . táblázatban szereplő módon határozza meg.

5. táblázat. A vizsgált minta kémiai összetétele

\begin{tabular}{|c|c|c|c|c|c|}
\hline elem [\%] & $\mathbf{C}$ & $\mathbf{P}$ & $\mathbf{S}$ & $\mathbf{C u}$ & $\mathbf{N}$ \\
\hline B500 & $\max 0,22$ & $\max .0,05$ & $\max 0,05$ & $\max .0,80$ & $\max .0,012$ \\
\hline
\end{tabular}

Forrás: MSZ EN 10080:2005. i. m. 31.

\subsection{Szakítóvizsgálat}

Az MSZ EN ISO 17660-1:200720 szabvány tartalmazza a betonacélok esetén alkalmazható hegesztési eljárásokat, illetve a releváns vizsgálati módszereket.

A hegesztőmühelytől készen kapott B500 anyagminőségű szálak végeit a varrattól 250-250 mm távolságban levágtuk. Zömítöhegesztésnél a kinyomódott sorját nem kell lemunkálni a vizsgálat előtt. ZD40 típusú szakítógéppel 400 kN méréshatárral az MSZ EN ISO 6892-1:2020 „Fémek. Szakítóvizsgálat. 1. rész: Vizsgálat szobahőmérsékleten” ${ }^{21}$ elöírásai szerint végeztük a vizsgálatokat. Az eredményeket a 6 . táblázat tartalmazza.

19 MSZ EN 10080:2005 „Betonacél. Hegeszthető betonacél. Általános követelmények”.

20 MSZ EN 10080:2005. i. m. 15.

21 MSZ EN ISO 6892-1:2020 „Fémek. Szakítóvizsgálat. 1. rész: Vizsgálat szobahőmérsékleten”. 
6. táblázat. A szakítóvizsgálat mérési eredményei

\begin{tabular}{|c|c|c|c|c|}
\hline \multicolumn{2}{|c|}{ A vizsgálat sorrendje } & $F_{m}$ & $R_{m}$ & Szakadás helye \\
\hline \multirow{4}{*}{$\varnothing 20$} & 1 & 118 & 376 & varratban \\
\hline & 2 & 167 & 532 & varratban \\
\hline & 3 & 151 & 481 & varratban \\
\hline & 4 & 152 & 484 & varratban \\
\hline U* & & 51,3 & 163,3 & \\
\hline \multirow{4}{*}{$\varnothing 25$} & 1 & 242 & 493 & varratban \\
\hline & 2 & 241 & 491 & varratban \\
\hline & 3 & 228 & 464 & varratban \\
\hline & 4 & 232 & 473 & varratban \\
\hline $\mathrm{U}^{*}$ & & 17,0 & 35,0 & \\
\hline \multirow{4}{*}{$\varnothing 28$} & 1 & 236 & 384 & varratban \\
\hline & 2 & 248 & 403 & varratban \\
\hline & 3 & 299 & 485 & varratban \\
\hline & 4 & 333 & 541 & varratban \\
\hline U* & & 112,2 & 181,5 & \\
\hline \multirow{2}{*}{$\varnothing 32$} & 1 & 287 & 357 & varratban \\
\hline & 2 & 339 & 422 & varratban \\
\hline $\mathrm{U}^{*}$ & & 91,3 & 114,1 & \\
\hline
\end{tabular}

* Kiterjesztett mérési bizonytalanság az MSZ EN ISO 6892-1:2020 szabvány²2 szerinti „A" eljárással számítva, ismételt mérésekkel.

Forrás: a szerzők szerkesztése

A vizsgálat során elért maximális erőből számítottuk a hegesztett pálcák szakítószilárdságát, amihez az MSZ EN ISO 15630:2020: „Betonacél és feszítőacél. Vizsgálati módszerek. 1. rész: Betonacél rúd, pálca és huzal" szabvány ${ }^{23}$ előírásai szerint a betonacél rudak névleges átmérőjéből számított keresztmetszetet használtuk fel. A B500 anyagminőségű betonacél folyáshatára minimum $500 \mathrm{MPa}$, szakítószilárdsága minimum $550 \mathrm{MPa}$. A táblázat alapján látható, hogy a hegesztés gyengíti a szerkezeteket, mivel egyik hegesztett pálca szakítószilárdsága sem éri el az alapanyag szakítószilárdságát. A szakadás minden esetben a varratban következett be, ami szintén arra utal, hogy az volt a próbatestek leggyengébb pontja. A mért eredmények átlaga $456 \mathrm{MPa}$ lett, ami 17\%-kal kevesebb, mint az alapanyagra előírt 550 MPa. A 32 mm átmérőjü próbatestből csak kettőt tudtunk vizsgálni, a leggyengébb szál

22 MSZ EN ISO 6892-1:2020. i. m. 24.

23 MSZ EN ISO 15630-1:2020 „Betonacél és feszítőacél. Vizsgálati módszerek. 1. rész: Betonacél rúd, pálca és huzal”. 
mégis a legvastagabbak között volt. Az ebben az esetben mért 357 MPa szakítószilárdság 65\%-a az alapanyagénak.

\subsection{A vizsgált zömítő tompahegesztéses toldás hatása a tartó teherbírására}

Egy hajlított gerenda méretezésén keresztül megvizsgáltuk annak hatását, hogy a toldott betonacélok szilárdságcsökkenése hogyan befolyásolja a tartó teherbírását. A méretezés során az volt a fő szempont, hogy az Eurocode 2 előírásainak ${ }^{24}$ megfelelve, olyan határhelyzetet ellenőrizzünk, amikor maximális kihasználtságon van a szerkezet. Ez esetünkben azt jelentette, hogy egysoros húzott vasalást terveztünk a tartóba, az egy keresztmetszetbe (a szerkesztési szabályoknak megfelelve) maximálisan elhelyezhető betonacélok mennyiségével.

A betonacélok toldására az Eurocode 2 azt írja elő, hogy egy keresztmetszetben toldható betonacélok mennyisége az alkalmazott betonacéloknak maximum harmada vagy negyede lehet kialakítástól függően, ezt a két határhelyzetet vizsgáltuk meg.

A szakítóvizsgálat alapján elmondható, hogy a toldott betonacélnak csökken a szilárdsága a toldási keresztmetszetben. Ezt a szilárdságcsökkenést százalékos értékben kifejezve meghatároztuk egy $60 \times 90 \mathrm{~cm}$ keresztmetszetü, C25/30 minőségü hajlító igénybevételnek kitett vasbeton gerendán keresztül, a korábban vizsgált $\varnothing 20, \varnothing 25, \varnothing 28, \varnothing 32$-es betonacél átmérők alkalmazásával. Az 5. ábra azt mutatja be, hogy amennyiben a toldott keresztmetszetben alkalmazott betonacélokban csökken a feszültség, milyen mértékben csökken a tartó hajlítónyomatéki ellenállása. A diagramban Ø28 (1/4) jelölés azt jelenti, hogy 28 mm átmérőjü betonacélokkal számoltunk, és az egy keresztmetszetben toldott betonacélok mennyisége a teljes húzott vasalás egynegyede.

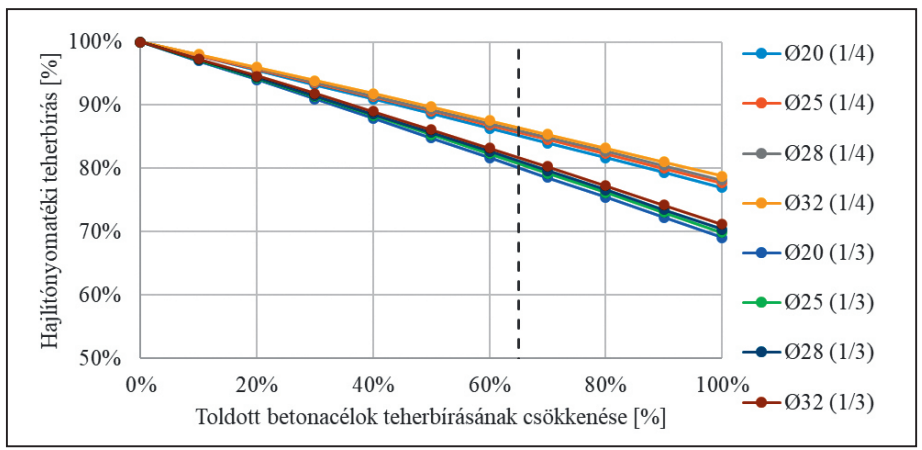

5. ábra. A keresztmetszet teherbírásának változása a toldott betonacélok szilárdságcsökkenésének függvényében Forrás: a szerzők szerkesztése

Az ábrán látható, hogy a vizsgált zömített toldások alkalmazása a teljes tartó teherbírását $1 / 4$ toldási mennyiség esetén körülbelül $85 \%$-ra, 1/3 toldási mennyiség esetén $80 \%$-ra csökkentette.

24 MSZ EN ISO 15630-1:2020. i. m. 7. 


\subsection{Szakító próbatestek töretvizsgálata}

Az előzőekben leírt módon elszakított hegesztett próbatestek töretfelületét vizsgáltuk. Az 6.a-b. ábrán szereplő felvételek fényképezőgéppel, míg a 6.c-f. felvételek Hitachi S-3400N típusú pásztázó elektronmikroszkóppal készültek a Ø25/2 sorszámú próbatestről. A többi próbatest törete is hasonló volt, de a nagyobb keresztmetszeteknél nagy zárványok fordultak elő, a 2.3. fejezetben leírt technológiából adódó problémák miatt. A képeken látható, hogy a kinyomódott sorja a vizsgálat során elkezdett leválni a betonacél rúdról. Maga a szál pedig kontrakció nélküli, rideg törést szenvedett, aminek eredménye a hasadásos - interkrisztallin töret. 1000-szeres nagyításban jól láthatók a hasadásos felületek, amelyek szintkülönbségének mértékéből lehet következtetni a hasadás terjedésére, ugyanis a hasadás későbbi szakaszaira nagyobb emelkedés jellemző. ${ }^{25}$

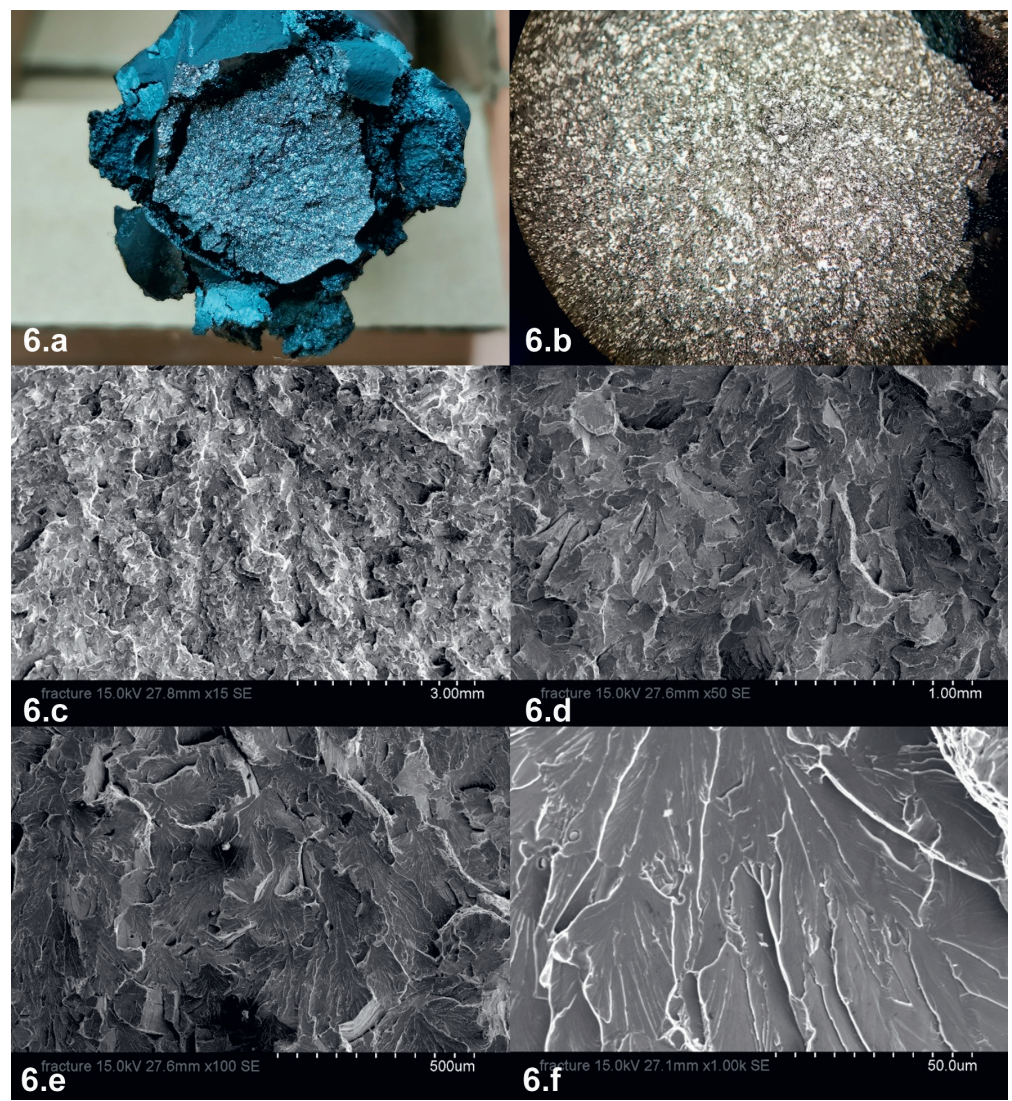

6. ábra. Szakító próbatest töretfelülete

Forrás: a szerzők felvételei

25 American Society for Metals: ASM Handbook. Volume 9. Fractography and Atlas of Fractographs. Ohio, Metals Park, 1987. 


\subsection{Keménységmérés}

A polírozott hosszmetszeten MSZ EN ISO 6507-1:2018 „Fémek. Vickers-keménységmérés. 1. rész: Mérési eljárás" szabvány ${ }^{26}$ előírásai szerint HV1 módszerrel mértük a minta keménységét. A varrat közepétöl 25-25 mm-es távolságban, egymástól 2 mm-re képeztünk lenyomatokat. Az eredményeket a 7. ábra tartalmazza.

MSZ EN ISO 15614-1:2017 „Fémek hegesztési utasítása és hegesztéstechnológiájának minősítése. A hegesztéstechnológia vizsgálata. 1. rész: Acélok ív- és lánghegesztése, valamint nikkel és ötvözetei ívhegesztése"27 szerint az 1 vagy 2 anyagcsoportba tartozó anyagok hegesztése esetén a mért keménységértékek nem haladhatják meg a 320 HV-t, ezt a követelményt maradéktalanul teljesíti a vizsgált varrat.

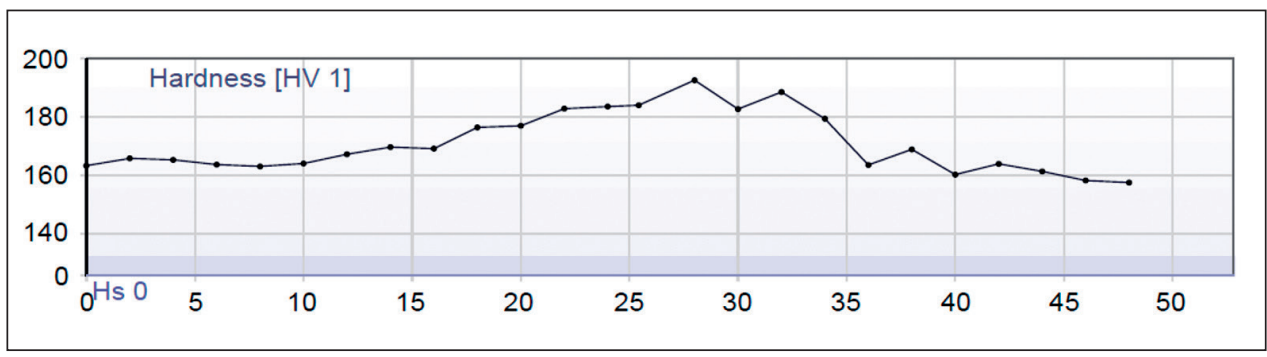

7. ábra. A próbatest hosszmetszetében mért keménység változása

Forrás: a szerzők szerkesztése

\subsection{Mikroszkópos vizsgálatok}

A keménységméréshez előkészített mintadarabot 6\% nitállal (salétromsav alkoholos oldata) történő maratásnak vetettük alá a mikroszkópos vizsgálatokhoz. A makrofelvételeket (8-10. ábra) Zeiss Stereo Discovery V20 sztereomikroszkóppal készítettük, a szövetszerkezeti vizsgálatokat (11-13. ábra) Zeiss Axiolmager M1 optikai mikroszkóppal végeztük. A hegesztési hő hatására végbemenő allotróp átalakulás következtében megváltozik az acél kristályszerkezete. A varratban, illetve a hőhatásövezetben jelentős szemcsedurvulás figyelhető meg, körülbelül $10 \mathrm{~mm}$ széles területen. Az alapszövet ferrit-perlites szerkezetü, az újrakristályosodási zónában ferrit, perlit és bainit figyelhető meg, a varratközép viszont a ferrithálóban durva tüs martenzitet tartalmaz, amely a kontrakció nélküli, rideg törést okozza a szakítóvizsgálat során.

26 MSZ EN ISO 6507-1:2018 „Fémek. Vickers-keménységmérés. 1. rész: Mérési eljárás”.

27 MSZ EN ISO 15614-1:2017 „Fémek hegesztési utasítása és hegesztéstechnológiájának minősítése. A hegesztéstechnológia vizsgálata. 1. rész: Acélok ív- és lánghegesztése, valamint nikkel és ötvözetei ívhegesztése". 


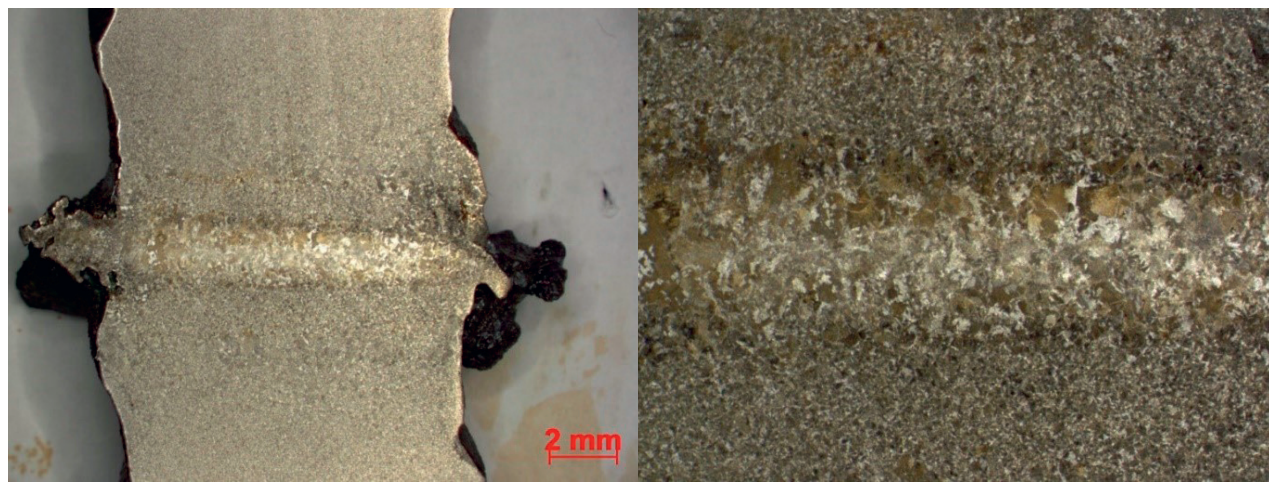

8. ábra. Sztereomikroszkópos felvétel a makrocsiszolatról

9. ábra. A varrat és a hőhatásövezet sztereomikroszkópos felvétele

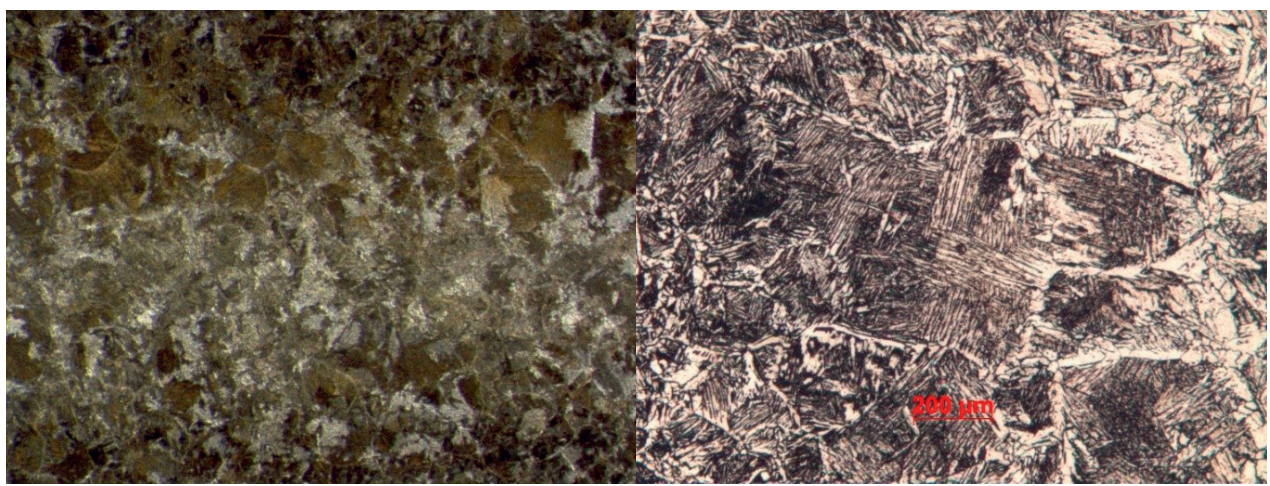

10. ábra. A varratközép sztereomikroszkópos felvétele

11. ábra. Varratközép mikroszkópos képe 50-szeres nagyításban

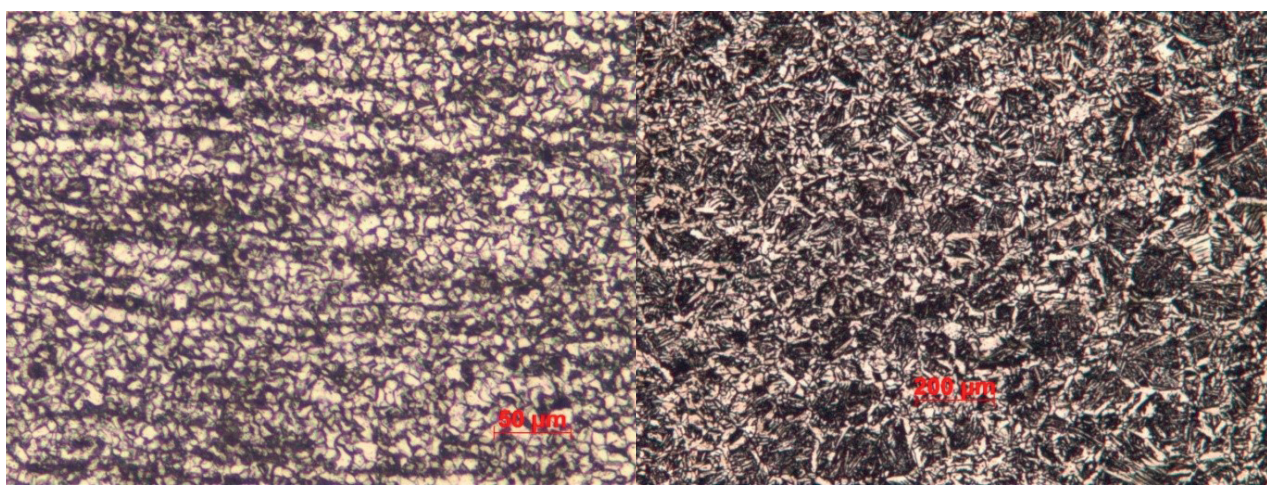

12. ábra. Alapszövet mikroszkópos képe 200-szoros nagyításban
13. ábra. Újrakristályosodási zóna mikroszkópos képe 200-szoros nagyításban

Forrás: a szerzők felvételei 


\section{5. Összefoglalás, következtetések}

Az ellenállás-tompahegesztéssel toldott betonacél szálak felhasználása az építőiparban még nem bevett gyakorlat. Az általunk vizsgált kisszámú minta alapján nem lehet kijelenteni, hogy ez a technológia alkalmas a nagyüzemi építkezések esetén is, viszont ha megfelelő körültekintéssel veszik figyelembe annak kockázatát, hogy a toldott kapcsolat esetén csökken a keresztmetszet teherbírása, akkor csökkenthető az építés során felhasznált betonacél mennyisége. A technológia további vizsgálatára, például hajlítóvizsgálatra és nagyobb számú próbatest kiértékelésére van szükség. A kockázati tényezők meghatározási módját az európai szabványok tartalmazzák. Megállapítottuk, hogy a hegesztett szálak egytengelyű húzó igénybevétellel szembeni ellenállása átlagosan körülbelül 80\%-a az alapanyagénak, illetve a hajlított tartó teherbírását is nagyjából ilyen mértékben befolyásolja a toldott szálak alkalmazása. A hagyományos metallográfiai vizsgálatok eredményei megfelelnek a vonatkozó szabványok előírásainak, így a vizsgált technológia a kockázati tényezők körültekintő figyelembevételével alkalmazható a vasbeton szerkezetekben.

\section{Felhasznált irodalom}

American Society for Metals: ASM Handbook. Volume 9. Fractography and Atlas of Fractographs. Ohio, Metals Park, 1987.

Altan, Taylan - Ngaile Gracious - Shen Gangshu: Cold and Hot Forging Fundamentals and Application. Ohio State University, 2004. Online: https://doi.org/10.31399/asm.tb.chffa.9781627083003

Bagyinszki Gyula - Czinege Imre: Fémek gyártási eljárásai. Győr, Széchenyi István Egyetem, 2006.

Baránszky-Jób Imre: Hegesztési kézikönyv. Budapest, Müszaki Könyvkiadó, 1985.

Deák György - Draskóczy András - Dulácska Endre - Kollár László - Visnovitz György: Vasbeton szerkezetek. Tervezés az Eurocode alapján. Budapest, Arfitex, 2016.

Farkas György - Huszár Zsolt - Kovács Tamás - Szalai Kálmán: Betonszerkezetek méretezése az Eurocode alapján. Közúti hidak, épületek. Budapest, TERC, 2008.

Gáti József: Hegesztési zsebkönyv. Budapest, Műszaki Könyvkiadó, 1995.

Gillemot László: Szerkezeti anyagok technológiája II. - Hegesztések. Budapest, Tankönyvkiadó, 1965.

Gunczer László: Anyagismeret és gyártástechnológia - Hegesztések modul. Szeged, Universitas-Szeged, 2009.

Lane, Susan - Danielle Kleinhans: FHWA LTBP Summary. National Changes in Bridge Practices for Reinforcing Bars. Concrete Reinforcing Steel Institute and Chair - National Concrete Bridge Council, 2016.

Lv, Yukun - Xuerou Zhao - Tuo Shi - Li Bai - XiuLan Liu - Jian Chen: Microstructure evolution of $400 \mathrm{MPa}$ class rebar produced by QST and VNM technology under the high strain and low cycle fatigue. Construction and Building Materials, 229. (2019), 116889. Online: https://doi. org/10.1016/j.conbuildmat.2019.116889

Song, Dan - Guowei Wang - Falin Yang - Huande Chen - Ningning Liang - Han Ma - Jinghua Jiang Xiaolong Ma: Microstructure and deformation behavior of anovel steel rebar. Effect of the heterogeneous microstructure of soft ferrite and hard bainite. Journal of Materials Research and Technology, (2020), 12281-12292. Online: https://doi.org/10.1016/j.jmrt.2020.08.085 
Tancsics, Ferenc - Tamás Ibriksz: Determining the optimum heating time of small sized test specimen made from weldable mild steel. Iop Conference Series. Materials Science and Engineering, 2020. Online: https://doi.org/10.1088/1757-899X/903/1/012033

Wei, Jie - Junhua Dong - Wei Ke: Corrosion resistant performance of a chemical quenched rebar in concrete. Construction and Building Materials, 25. (2011), 1243-1247. Online: https://doi. org/10.1016/j.conbuildmat.2010.09.029

Yan, Dongming - Hao Qian - Zhenwen Xu - Shikun Chen - Genda Chen: Microstructural and mechanical characterization of the interface between concrete and chemically reactive enamel (CRE) coated rebar. Construction and Building Materials, (2020). Online: https://doi.org/10.1016/j. conbuildmat.2020.120676

\section{Elöírások, szabványok}

Közlekedés- és Postaügyi Minisztérium: Különleges feltételek a közúti hidak betonacél hegesztésére. Budapest, 1967.

MSZ EN 1992-1-1:2004/A1:2016 Eurocode 2: „Betonszerkezetek tervezése. 1-1. rész: Általános és az épületekre vonatkozó szabályok"

MSZ EN 10080:2005 „Betonacél. Hegeszthető betonacél. Általános követelmények”

MSZ EN ISO 17660-1:2007 „Hegesztés. Betonacélok hegesztése. 1. rész: Teherhordó hegesztett kötések"

MSZ EN ISO 15614-1:2017 „Fémek hegesztési utasítása és hegesztéstechnológiájának minősítése. A hegesztéstechnológia vizsgálata. 1. rész: Acélok ív- és lánghegesztése, valamint nikkel és ötvözetei ívhegesztése"

MSZ EN 1090-2:2018 „Acél- és alumíniumszerkezetek kivitelezése. 2. rész: Acélszerkezetek műszaki követelményei"

MSZ EN ISO 6507-1:2018 „Fémek. Vickers-keménységmérés. 1. rész: Mérési eljárás"

MSZ EN ISO 6892-1:2020 „Fémek. Szakítóvizsgálat. 1. rész: Vizsgálat szobahőmérsékleten”

MSZ EN ISO 15630-1:2020 „Betonacél és feszítőacél. Vizsgálati módszerek. 1. rész: Betonacél rúd, pálca és huzal"

\section{Internetes forrás}

https://bau-haus.hu/megjelenites/393ktR2kU8C5VyLIGbetonacelto-prsldoszerkezF87lqSwwU 